\title{
Circulation epochs based on the Vangengeim-Girs large scale patterns (1891-2010)
}

\section{Epoki cyrkulacyjne w serii makroform Vangengeima-Girsa (1891-2010)}

\begin{abstract}
This paper presents the results of an investigation of the variability in macro-circulation forms at the mid-tropospheric level distinguished in the Vangengeim-Girs (V-G) classification. The annual frequencies of circulation forms in the years 1891-2010 proved significant fluctuations, which provided the basis for distinguishing 7 circulation epochs. The epochs illustrate secular changes in the character of dominant forms - zonal circulation (W) prevailed at the turn of the 20th century; meridional forms E and C developed next, and zonal circulation began to dominate again after 1990.

Keywords The Vangengeim-Girs classification, macro-circulation forms, circulation epochs.

Zarys treści W pracy przedstawiono wyniki badań zmienności makroform cyrkulacji w środkowej troposferze, wyszczególnionych w klasyfikacji Vangengeima-Girsa (V-G). Roczne częstości form cyrkulacji w latach 1891-2010 wykazały znaczące wahania, które stanowiły podstawę wyróżnienia 7 epok cyrkulacyjnych. Epoki te ilustrują wiekowe zmiany dominujących makroform - na przełomie XIX i XX wieku panowała strefowa cyrkulacja (W); później rozwinęły się formy południkowe E i C, a po 1990 roku ponownie zaczęła dominować strefowa cyrkulacja.
\end{abstract}

Słowa kluczowe Klasyfikacja Vangengeima-Girsa, makroformy cyrkulacji, epoki cyrkulacyjne.

\section{Introduction}

The classification of mid-tropospheric macroforms created in the former USSR in the mid- $20^{\text {th }}$ century is one of well-known though not commonly used (Vangengeim 1935, 1946, 1952; Girs 1964, 1971, 1974, 1977, 1981). The Vangengeim-Girs (V-G) classification assembles a variety of circulation patterns (so-called elementary synoptic processes) in just a few basic classes, which define the zonal (W) and meridional ( $\mathrm{E}, \mathrm{C}$ ) types (V-G macroforms) in the extratropical Northern Hemisphere $\left(30-80^{\circ} \mathrm{N}\right)$. From the beginning, the use of the $\mathrm{V}-\mathrm{G}$ classification was accompanied by the idea that the variability of circulation patterns is characterized by regular fluctuations, forming, in the long-term perspective, the so-called circulation epochs - periods covering several years to decades with certain circulation forms dominating. According to some research studies, circulation epochs are related to secular variations of solar and geomagnetic activity, and also to the Earth's rotation angular speed (e.g. Lambeck 1980; Sidorenkov and Orlov 2008).

In this study circulation epochs were identified in the period 1891-2010 and compared with the epochs previously known from various publications.

\section{Data and methods}

The monthly frequencies of V-G macroforms for 18911948 published by Bolotinskaya and Ryzhakov (1964) and the calendar of daily V-G macroforms for the period 1 January 1949 - 31 December 2010 provided the data-base for this study. The 1949-2005 data were obtained from Dimitrieev and Belyazo (2006). Data for 2006-2010 were obtained from the Arctic and Antarctic Research Institute in Petersburg. In summary, 120-year records of annual frequencies of V-G macroforms were obtained, covering the period 1891-2010. Marsz's opinion (2013: 10) that "the V-G series is homogeneous without a doubt" was accepted. Sepp (2005: 35) confirmed that "mistakes in V-G classification are less probable". However, it should be remembered that the subjective ("manual") classification of circulation forms, prepared by different authors over many years, cannot unconditionally guarantee time series homogeneity. "Highly positive persistence trends detected in the subjective Hess-Brezowsky classification" may serve as an example of unrealistic climate shift induced by the change in the procedures of H-B classification production (Kucerová et al. 2017: 2518).

The cumulative deviations of macroforms annual frequencies were used as a basis to distinguish circulation epochs in the analyzed long-term period, as in other studies on circulation epochs (e.g. Girs 1977; Sidorenkov and Svirenko 1983; Sepp 2011). An epoch was assumed 
to last no less than 5 years, while accepting the fact that such short periods would not fully correspond to the meaning of the term "epoch".

Additionally, the cumulative standard deviations (STD $\Sigma$ ) were determined, allowing to assess the statistical significance of the fluctuations observed in the analyzed time series. The following formula was used:

$$
\operatorname{STD} \Sigma_{i}=\operatorname{STD} \sqrt{i-i^{2} / n}
$$

where: STD is a standard deviation, $i$ indicates position in the record, $n$ specifies the length of the record $(n=120)$.

The t-test was applied to assess the statistical significance of the differences between epoch-averaged V-G annual frequencies and the long-term average. The circulation index was assigned to each epoch, indicating the relative surplus (deficiency) in the macro-circulation form $W(E), W(C)$ and $E(C)$. Relative predominance of $W$ over $E$ and $C$ forms, as well as the prevalence of $E$ in relation to $C$ form was indicated by the positive deviations of the ratios $\mathrm{fW} / \mathrm{fE}, \mathrm{fW} / \mathrm{fC}$ and $\mathrm{fE} / \mathrm{fC}$ from their average values. Negative deviations indicate the domination of $E$, $C$ and $C$ forms, respectively. For example, the ECE index indicates that the quotients $\mathrm{fW} / \mathrm{fE}$ and $\mathrm{fW} / \mathrm{fC}$ are smaller, and $\mathrm{fE} / \mathrm{fC}$ greater than their average values.

\section{Delimitation of circulation epochs}

The cumulative deviations series show significant instability of macro-circulation form frequencies. The maxima and minima of $\Sigma \Delta f$, visible on the graphs, go far beyond the range limited by 3 standard deviations (STDE). The frequency of $W$ type shows the largest cumulative deviations. The $\Sigma \Delta \mathrm{f}$ related to the $\mathrm{C}$ form are relatively small (Fig. 1).

The maximum of cumulative deviation curve, which occurred in 1932 and amounted to 6,46 standard deviations STDE, indicates substantial instability of the $W$ macroform frequency. In the case of $E$ form frequency, the greatest deviation occurred in 1949 and was equal to 5,66 STD $\Sigma$. The course of $C$ form deviations had a maximum in 1971 , represented by 3,18 STD $\Sigma$. Fluctuations in $\Sigma \Delta f$ of macroforms differ significantly from random fluctuations in the time series of independent elements.

Two periods of dominating, above-average frequencies of $W$ form in the years 1891-1932 and 19922010 are visible on the cumulated deviations plots. Positive E form anomalies prevailed in 1933-1937 and 1950-1990. Above-average $\mathrm{C}$ form frequencies were the most prevalent until 1902 and in the period 1939-1969 (Fig. 1).

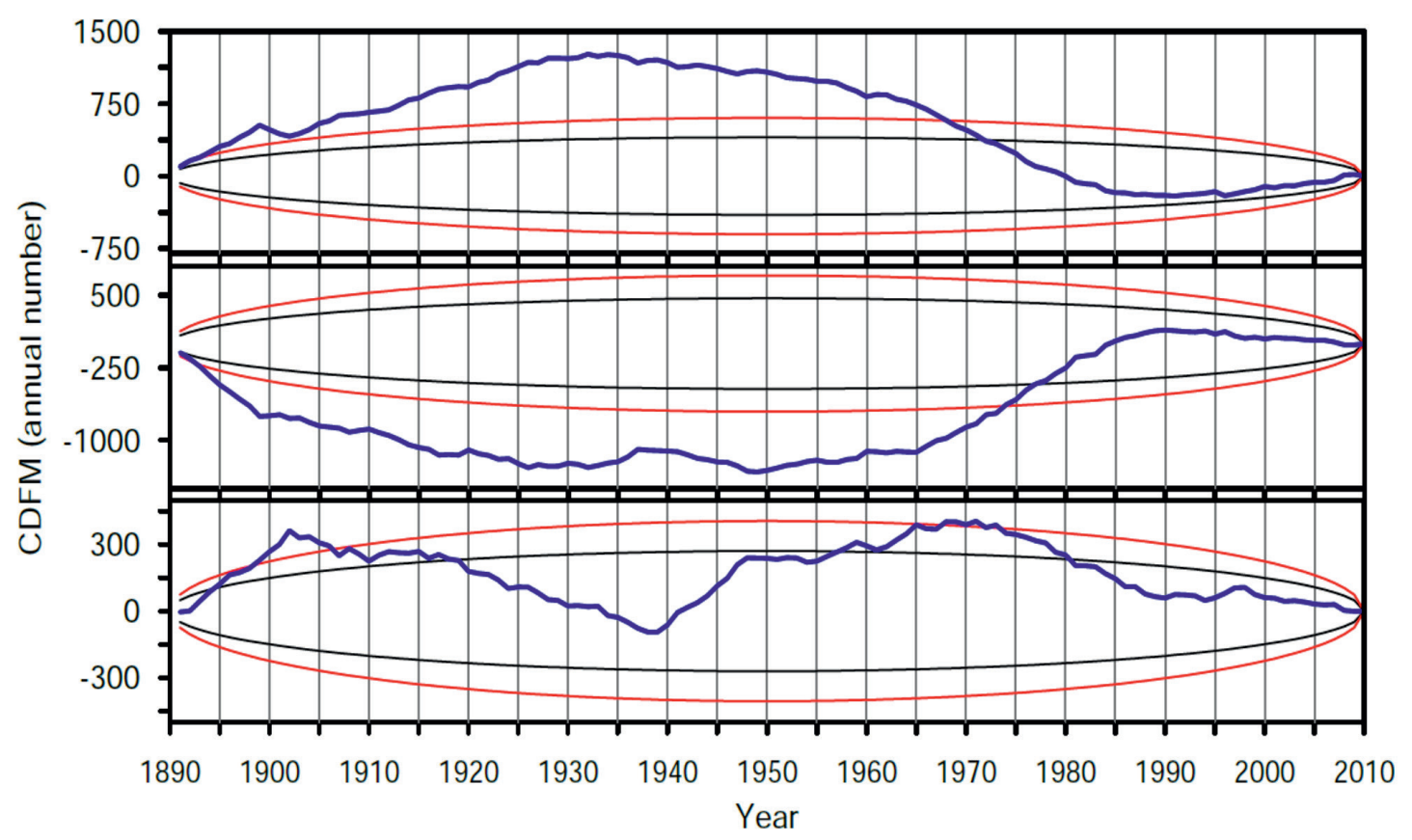

Fig. 1. Cumulative deviations from the mean (CDFM) annual number of the Vangengeim-Girs macroform. W (top), E (middle) and C (bottom) in the period 1891-2010. Elipses indicate 95 and 99\% confidence intervals

Ryc. 1. Kumulowane odchylenia od średniej rocznej częstości makroform Vangengeima-Girsa w okresie 1891-2010. W (górny panel), E (środkowy), C (dolny). Elipsy przedstawiają 95 i 99\% zakresy ufności 
Seven circulation epochs were distinguished in the analyzed period 1891-2010 with a duration of 6 to 30 years. The differences between the epoch-averaged frequencies $\mathrm{fW}, \mathrm{fE}$ and $\mathrm{fC}$ are almost twice as high as the average year-to-year frequency changes (Tab. 1, Tab. 2). The average annual frequencies in 5 epochs are significantly different from the average for the entire period 1891-2010 (Tab. 2).
Table 1. The average year-to-year changes in the annual frequencies of V-G macro-circulation forms (fW, fE, fC) in the period 1891-2010

Tabela 1. Średnie zmiany z roku na rok rocznych częstości makroform V-G (fW, fE, fC) w okresie 1891-2010

\begin{tabular}{cc}
\hline $\begin{array}{c}\text { V-G form } \\
\text { Formy V-G }\end{array}$ & $\begin{array}{c}\text { Average change (days/year) } \\
\text { Średnia zmiana (dni/rok) }\end{array}$ \\
\hline W & 24.6 \\
E & 28.9 \\
C & 21.4 \\
\hline
\end{tabular}

Source/Źródło: own elaboration/opr. własne.

Table 2. The V-G circulation epochs, mean and maximum frequencies ( $f, \%)$, statistical significance of deviations from the long-term average according to t-test and index of the circulation epoch

Tabela 2. Epoki cyrkulacyjne V-G, średnie i maksymalne częstości (f, \%), istotność statystyczna odchyleń częstości od średniej wieloletniej na podstawie statystyki t-studenta oraz indeks cyrkulacji w epoce

\begin{tabular}{|c|c|c|c|c|c|c|c|c|c|}
\hline \multirow{2}{*}{$\begin{array}{l}\text { Period } \\
\text { Okres }\end{array}$} & \multirow{2}{*}{$\begin{array}{l}\text { Epoch } \\
\text { Epoka }\end{array}$} & \multicolumn{3}{|c|}{$\begin{array}{l}\text { Mean frequency } \\
\text { Średnia częstość }\end{array}$} & \multirow{2}{*}{$\begin{array}{l}\text { Maximum frequency (year) } \\
\text { Maksymalna częstość (rok) }\end{array}$} & \multicolumn{3}{|c|}{$\begin{array}{l}\text { t-statistic } \\
\text { statystyka t }\end{array}$} & \multirow{2}{*}{$\begin{array}{l}\text { Index } \\
\text { Indeks }\end{array}$} \\
\hline & & W & $E$ & C & & W & $\mathrm{E}$ & C & \\
\hline 1891-1902 & $w+C$ & 42.6 & 23.7 & 33.7 & $\begin{array}{l}f W=60.3(1891) \\
f C=42.7(1902)\end{array}$ & 3.56 & -6.29 & 4.86 & WCC \\
\hline 1903-1932 & W & 41.0 & 36.8 & 22.2 & $f W=51.0(1923)$ & 5.43 & -2.55 & -3.01 & WWE \\
\hline 1933-1938 & $\mathrm{E}$ & 30.2 & 49.6 & 20.2 & $f E=63.3(1937)$ & -0.74 & 1.75 & -1.94 & EWE \\
\hline 1939-1949 & C & 30.5 & 35.8 & 33.7 & $f C=42.2(1947)$ & -0.93 & -1.66 & 4.59 & WCC \\
\hline 1950-1969 & $E+C$ & 25.4 & 47.0 & 27.6 & $\begin{array}{l}f E=61.4(1960) \\
f C=36.7(1965)\end{array}$ & -4.04 & 2.36 & 1.63 & ECE \\
\hline 1970-1991 & $\mathrm{E}$ & 24.1 & 54.6 & 21.3 & $f E=71.8(1981)$ & -5.12 & 6.77 & -3.24 & ECE \\
\hline 1992-2010 & W & 36.2 & 39.5 & 24.3 & $f W=49.0(2008)$ & 1.41 & -0.77 & -0.75 & WWC \\
\hline 1891-2010 & - & 33.2 & 41.4 & 25.4 & - & - & - & - & - \\
\hline
\end{tabular}

Frequencies determining the character of epoch as well as values of t-statistics significant at 0,05 level are in bold Częstości określające charakter epoki oraz wartości statystyki t istotne na poziomie 0,05 pogrubiono

Source/Źródło: own elaboration/opr. własne.

During the first epoch, lasting until 1902, the W and $C$ forms dominated and their frequencies of occurrence differed significantly from the long-term averages $(p<0,01)$. The highest frequencies of $W$ and $C$ patterns over the entire analyzed period occurred in this epoch. The epoch index - WCC - indicates that the frequency of $C$ form showed surpluses both in relation to the average $\mathrm{fE}$ and $\mathrm{fW}$. This epoch was characterized by the prevalence of $\mathrm{W}$ zonal circulation with a large contribution of $\mathrm{C}$ meridional circulation $-(\mathrm{W}+\mathrm{C})$.

During the epoch lasting between 1903 and 1932, the W type prevailed; its frequency was significantly higher than the average $(p<0,01)$. The $W$-epoch $(1903-32)$ was marked by a decrease in the $C$ form frequency of 42 days/year (i.e. $34 \%$ of the average for the preceding $\mathrm{W}+\mathrm{C}$ period). The share of meridional $\mathrm{E}$ and $\mathrm{C}$ forms was small; therefore, this period may be identified as the zonal flow dominance epoch (W).

In the years 1933-1938, the frequency of $E$ form exceeded the average; however, the $\Delta \mathrm{fE}$ anomaly was insignificant $(p=0,08)$. In the E-epoch, a decrease in $\mathrm{fW}$ of 39,5 days/year, i.e. $26 \%$, and an increase in $\mathrm{fE}$ of 40,8 days/year, i.e. $35 \%$ of the average for the preceding
W-epoch, is observed. A drop in the C form frequency which can be considered significant $(p=0,05)$ is characteristic of this epoch. The circulation index (EWE) indicates that the $\mathrm{E}$ meridional pattern dominated in this period; however, it is worth emphasizing that the frequencies of all V-G forms were close to the long-term average during this epoch.

Significant anomalies occurring in the period 193949 were characterized by a substantial increase in the C form frequency (of 49,3 days/year, i.e. as much as $67 \%$ ), whereas the fE frequency decreased by 50,4 days/ year (i.e. $28 \%$ ). The positive anomaly $\Delta \mathrm{fC}$ was statistically significant $(p<0,01)$. During this epoch, the frequencies $W$ as compared to $E$ reached an above-average frequency ratio, while $\mathrm{fC}$ showed a relative dominance over the $\mathrm{fE}$ and fW frequencies (index: WCC). This was the C meridional circulation epoch.

In the years 1950-1969, the high fC values persisted and, additionally, the $\mathrm{E}$ macroform frequency was on the rise - the positive anomaly $\Delta \mathrm{fE}$ in this period is deemed statistically significant $(p<0,05)$. The increase in $\mathrm{fE}$ was 40.9 days/year (i.e. 32\% of the preceding epoch's average). It was the $\mathrm{E}+\mathrm{C}$ epoch. 
From 1970 to 1991, the E pattern was dominant. A further increase in $\mathrm{fE}$ (of 27,7 days/year, i.e. 16\%) and a decrease in $\mathrm{fC}$ of 23 days/year, i.e. $23 \%$ of the average for the preceding period, were observed. The $\Delta \mathrm{fE}$ anomaly is highly significant $(p<0,01)$. In 1981 , the fE frequency reached a long-term maximum: $71,8 \%$ of days per year. This was the $E$ meridional circulation epoch, lasting for 22 years.

Since 1992, the frequency of $W$ zonal circulation form has been increasing. The $\mathrm{fW}$ frequency has risen by 44,2 days/year, i.e. $50 \%$ of the frequency for the preceding epoch, while the fE frequency has decreased by 55,1 days/year, i.e. $28 \%$. However, the positive anomaly $\Delta \mathrm{fW}$ is not significant $(\mathrm{p}=0,16)$ and other frequencies are barely different from the long-term average. The growing $\mathrm{fW}$ and its relation to $\mathrm{FE}$ and $\mathrm{fC}$ (index WWC) allow to identify the period as the epoch of moderate development of zonal circulation (W).

The series of circulation indices, presented in Tab. 3, provide a more detailed description of the variability of $\mathrm{W}, \mathrm{E}$ and $\mathrm{C}$ forms and their mutual relations. The ECE is the most frequently occurring index in the multi-year period (22,5\% of cases), indicating an excess of fE frequency in relation to $\mathrm{fW}$ as well as $\mathrm{fC}$ and a deficit of $\mathrm{fW}$ in relation to $\mathrm{fC}$; this relation is a distinctive feature of E-epochs. The WWC relation, typical of W-epochs, is almost as frequent (20\% of cases).

Table 3. The annual indices of circulation according to the quotients of annual frequencies - $\mathrm{fW} / \mathrm{fE}, \mathrm{fW} / \mathrm{fC}, \mathrm{fE} / \mathrm{fC}$ and their total number (\%) in the period 1891-2010

Tabela 3. Roczne indeksy cyrkulacji określone na podstawie ilorazów rocznych częstości - fW/fE, fW/fC, fE/fC oraz ich łączna częstość (\%) w okresie 1891-2010

\begin{tabular}{|c|c|c|c|c|c|c|c|c|c|c|c|}
\hline \multirow{2}{*}{$\begin{array}{l}\text { Year } \\
\text { Rok }\end{array}$} & \multicolumn{10}{|c|}{ Year $+\ldots$ / Rok $+\ldots$} & \multirow{2}{*}{$\begin{array}{l}\text { Decade } \\
\text { Dekada } \\
1-10\end{array}$} \\
\hline & +1 & +2 & +3 & +4 & +5 & +6 & +7 & +8 & +9 & +10 & \\
\hline 1890 & WWC & WWC & WCC & WCC & WWC & WCC & WWC & WWC & WWC & ECC & WWC \\
\hline 1900 & ECC & WCC & WWE & WWC & WWE & WWE & WWE & WCC & EWE & WWE & WWC \\
\hline 1910 & WCC & WCC & WWC & WWC & WWC & WWE & WWC & WWE & WWE & EWE & WWC \\
\hline 1920 & WWC & WWC & WWE & WWE & WWC & WWC & EWE & WWE & EWE & EWE & WWE \\
\hline 1930 & WWC & WWC & ECE & EWE & EWE & EWE & ECE & WWE & WWC & ECC & EWE \\
\hline 1940 & ECC & WCC & WCC & ECC & ECC & ECC & WCC & WCC & WWC & ECE & WCC \\
\hline 1950 & ECE & ECE & ECE & EWE & ECE & WCC & ECC & ECC & ECC & ECE & ECE \\
\hline 1960 & WWE & WCC & ECC & ECC & ECC & ECE & ECE & ECC & ECE & ECE & ECE \\
\hline 1970 & ECE & ECE & ECC & ECE & ECE & ECE & ECE & ECE & EWE & ECE & ECE \\
\hline 1980 & ECE & ECE & ECE & ECE & EWE & EWE & ECE & EWE & EWE & EWE & EWE \\
\hline 1990 & ECC & WWC & WWE & EWE & WWC & ECC & WCC & WWC & WWE & WWE & WWC \\
\hline 2000 & ECE & WWE & WCC & WWC & WWE & EWE & WWC & WWE & WWE & ECE & WWE \\
\hline \multicolumn{12}{|c|}{ 1891-2010 } \\
\hline ECE & 22.5 & WWC & 20.0 & WWE & 16.6 & ECC & 14.2 & EWE & 14.2 & WCC & 12.5 \\
\hline
\end{tabular}

Source/Źródło: own elaboration/opr. własne.

The circulation epochs, delimited in this study, should be compared with epochs, distinguished according to other criteria, as well as with the original classification by Girs (1977) and other Russian researchers (Tab. 4). Different assessments of changes in circulation patterns since the end of the $19^{\text {th }}$ century have provided congruent results. Notably, a secular quasi-cycle can be discerned in the changes of Vangengeim-Girs mid-tropospheric macro-circulation forms. The time boundaries of circu- lation epochs and the periods of prevalence of zonal or meridional circulation reveal the existence of such periodicity. The development of zonal circulation at the turn of the $21^{\text {st }}$ century remains in phase with this cycle. It is worth mentioning that the forecast "in future - until the end of the twentieth century - the zonal forms of circulation will increase" (Kożuchowski and Marciniak 1988: 197) has proved correct. 
Table 4. The circulation epochs according to various studies - years of the beginning and the end of epoch and bold symbols indicating the intensity of zonal circulation during the epoch (see explanations below) Tabela 4. Epoki cyrkulacyjne według wybranych opracowań - zaznaczono lata początku i końca epok, symbole pogrubione wskazują na stopień intensywności cyrkulacji strefowej w epoce (zob. wyjaśnienia pod tabelą)

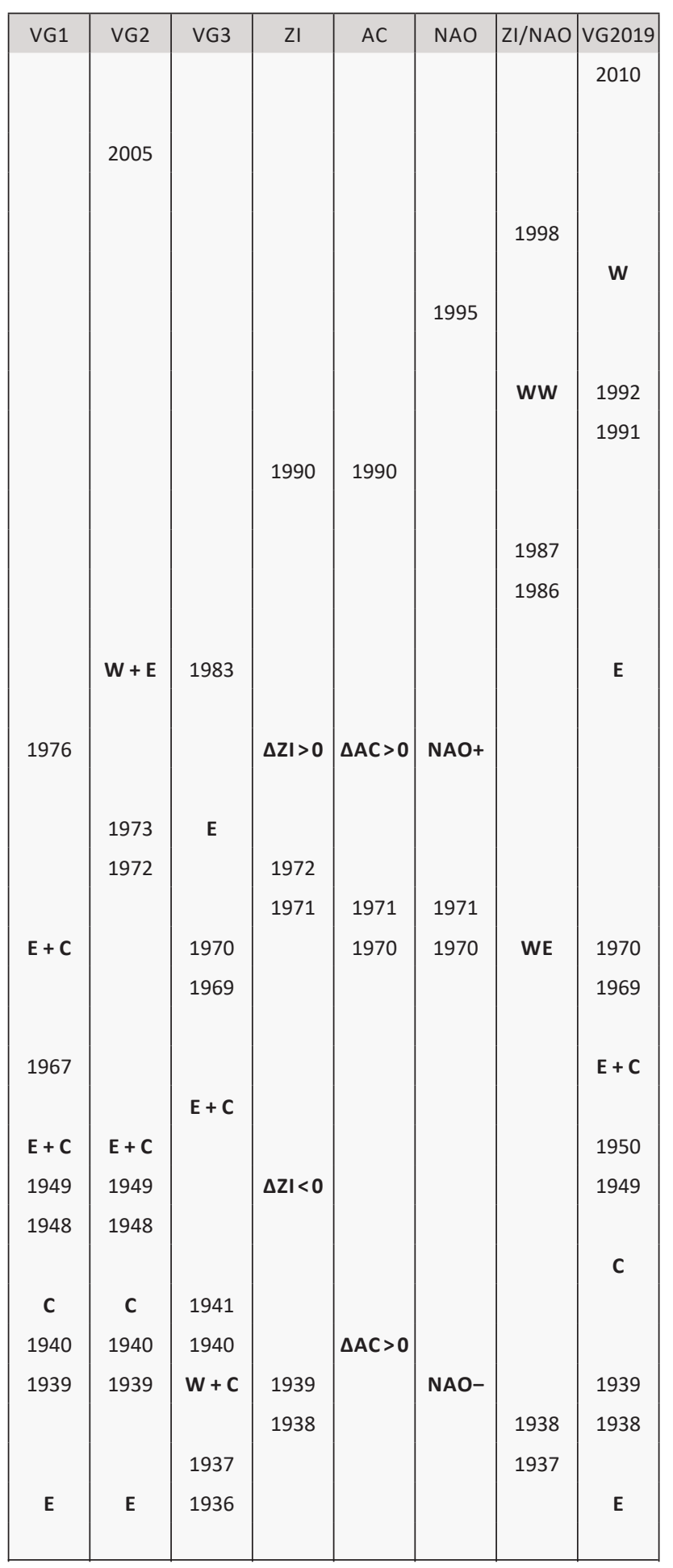

Table 4 continued/Tabela $4 \mathrm{~cd}$.

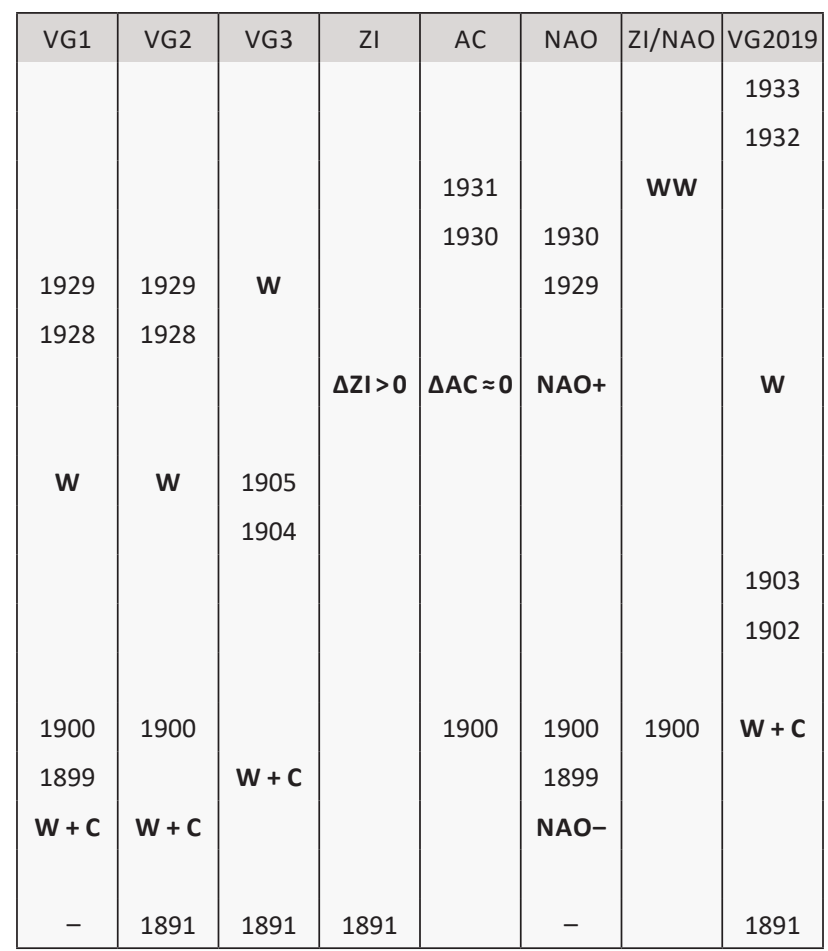

VG1 - V-G epochs according to Girs (1977);

VG2 - V-G epochs according to Sidorenkov and Svirenko (1983);

VG3 - V-G epochs according to Gorbačeva (1986);

$\mathrm{ZI}$ - epochs of intense $(\Delta \mathrm{ZI}>0)$ and weak $(\Delta \mathrm{ZI}<0)$ zonal circulation distinguished on the basis of the meridional pressure gradient (SLP difference between 35 and $65^{\circ} \mathrm{N}$ - zonalindex) (Kożuchowski 1993);

AC - index of zonal circulation over Europe, calculated on the basis of the deviation from the average number of strong anticyclones in the south of Europe and the number of deep cyclones in the north $(\triangle A C>0$, $\triangle \mathrm{AC} \approx 0, \triangle \mathrm{AC}<0$ - strong, moderate and weak zonality, respectively) (Kożuchowski 1995);

$\mathrm{NAO}$ - epochs of positive (NAO+) and negative phase (NAO-) dominance of the North Atlantic Oscillation according to Marsz (1999);

ZI/NAO - epochs of intense (WW) and weak (WE) zonal circulation determined on the basis of zonalindex $35-65^{\circ} \mathrm{N}$ and NAO index (Degirmendžić et al. 2000);

VG2019 - V-G circulation epochs presented in this study.

VG1 - epoki V-G według Girsa (1977);

VG2 - epoki V-G według Sidorenkov i Svirenko (1983);

VG3 - epoki V-G według Gorbačeva (1986);

ZI - okresy intensywnej $(\Delta \mathrm{ZI}>0)$ i słabej $(\Delta \mathrm{ZI} 0)$ cyrkulacji strefowej określonej na podstawie południkowego gradientu ciśnienia (różnica SLP między 35 a $65^{\circ} \mathrm{N}$ - zonal indeks) (Kożuchowski 1993);

AC - indeks cyrkulacji strefowej w Europie, obliczony na podstawie odchylenia od średniej liczby silnych antycyklonów na południu Europy i liczby głębokich cyklonów na północy $(\triangle A C>0, \triangle A C \approx 0$, $\triangle \mathrm{AC}<0$ - silna, umiarkowana i słaba strefowość, odpowiednio) (Kożuchowski 1995);

$\mathrm{NAO}$ - epoki dodatniej (NAO+) i ujemnej fazy (NAO-) oscylacji północnoatlantyckiej według Marsza (1999);

ZI/NAO - epoki intensywnej (WW) i słabej (WE) cyrkulacji strefowej wyznaczone na podstawie zonal indeksu $35-65^{\circ} \mathrm{N}$ i wskaźnika NAO (Degirmendžić i in. 2000);

VG2019 - epoki cyrkulacyjne V-G przedstawione w niniejszej pracy. 


\section{Summary and discussion}

In the period 1891-2010, significant multi-annual fluctuations in the frequency of macroforms took place. An analysis of these fluctuations enabled the identification of 7 circulation epochs whose recurrence suggests that a secular quasi cycle is present in the changes of $\mathrm{V}-\mathrm{G}$ forms; from the end of the $19^{\text {th }}$ century, the zonal circulation dominated, followed by the meridional circulation epoch, and finally, since the end of 1990s, the zonal circulation has started to prevail again.

Circulation epochs represent a synthetic description of over 100-year history of changes in the circulation conditions in the Atlantic-Eurasian sector of temperate latitudes. Moreover, delimitating the epochs enabled the observation of the characteristic correlation of some climate events since the late $19^{\text {th }}$ century with the dominant forms of circulation in the middle troposphere. In general, the rule known for a long time has been confirmed: meridional circulation forms are associated with climate cooling, while zonal forms with warming (Lamb 1972; Lambeck et al. 1980). For example, the domination of zonal circulation at the beginning of the $20^{\text {th }}$ century coincided with rapid warming in the Subarctic area, and the prevalence of $C$ form in the 1940s correlated with a cold climate period; the last complete freezing of the Baltic Sea in 1947 was one of the symptoms of that cooling. The subsequent epoch $(E+C)$ co-occurred with the well-known slowdown in global warming in the 1960s. The reduced contribution of C forms in the subsequent years corresponds to the most recent phase of warming in the final decades of the $20^{\text {th }}$ century and at the beginning of the $21^{\text {st }}$ century.

\section{Acknowledgements}

We are grateful to Dr. V.E. Laguna (Arctic and Antarctic Research Institute, St Petersburg, Russia) and to Prof. A.A. Marsz (Gdynia Maritime University, Poland) for providing the calendar of the Vangengeim-Girs macro-circulation forms, used in this study.

\section{References}

Bolotinskaja, M.S., Ryzhakov, L.J., 1964. Katalog makrosinopticzeskih protsessov po klassifikacij G.J. Vangengeima 1891-1962 (Catalogue of macro-synoptic processes according to the G.J. Vangengeim's classification 1891-1962). AANII Leningrad, 1-158 [in Russian].

Degirmendžić, J., Kożuchowski, K., Wibig, J., 2000. Epoki cyrkulacyjne w XX wieku i zmienność typów cyrkulacji w Polsce (Circulation epochs in the $20^{\text {th }}$ century and variation of the types of atmospheric circulation in Poland). Przegląd Geofizyczny 45, 221-238 [in Polish].

Dimitrieev, A.A., Belyazo, V.A., 2006. Kalendarnyj katalog atmosfernykh processov po cirkumpolarnoj zonie severnogo polushariya i ikh kharakteristiki za period s 1949 po 2005 g (Calendar catalogue of atmospheric processes in the Northern Hemisphere circumpolar zone and their characteristics in the period 1949-2005), [w:] Kosmos, planetarnaya klimaticheskaya izmenchivost' i atmosfera polarnykh regionov. Gidrometeoizdat, St. Petersburg, 1-358 [in Russian].

Girs, A.A., 1964. O sozdanii iedinoi klassifikacii makrosinopticheskikh processov severnogo polushariya (About defining the simple classification of macro-synoptic processes in the Northern Hemisphere). Meteorologia i Gidrologia 4, 43-47 [in Russian].
Girs, A.A., 1971. Mnogoletniie kolebaniia atmosfernoi cirkulacii i dolgosrochnye gidrometeorologicheskye prognozy (Multi-year fluctuations of atmospheric circulation and long-term hydro-meteorological forecasts). Gidrometeoizdat, Leningrad, 1-280 [in Russian].

Girs, A.A., 1974. Makrocirkulacyonnyi metod dolgosrochnykh meteorologicheskikh prognozov (Macro-circulation method of long-term meteorological forecasts). Gidrometeoizdat, Leningrad, 1-488 [in Russian]

Girs, A.A., 1977. Mnogoletnye preobrazovaniya form atmosfernoy curkulacii i kolebaniya klimatov razlichnykh rayonov severnogo poluscharyia (Long-term transformation of the atmospheric circulation forms and fluctuations of climate in different regions of the Northern Hemisphere), [w:] Klimatologia i sverhdolgosrochnyj prognoz. Gidrometeoizdat, Leningrad, 39-46 [in Russian].

Girs, A.A., 1981. K voprosu o formakh atmosfernoi cirkulacii i ikh prognosticheskom ispolzovanii (Problem of the atmospheric circulation forms and their application for the forecasts). Trudy AANII 374, 4-13 [in Russian].

Gorbačeva, N.A., 1986. K voprosu ob obiektivnykh pokazatelyakh klassifikacyi G. la. Vangengeima - A.A. Girsa (Problems of the objective indices in the G.Ya. Vangengeim - A.A. Girs classification). Trudy VNII, Gidrometeorol. Inform., 1-129 [in Russian].

Kożuchowski, K.M., 1993. Variations of hemispheric zonal index since 1899 and its relationships with air temperature. International Journal of Climatology 13, 853-864, https://doi.org/10.1002/ joc.3370130804.

Kożuchowski, K.M., 1995. Głębokie cyklony, antycyklony i cyrkulacja strefowa nad Europą (1900-1990) (Deep cyclones, anticyclones and zonal circulation over Europe, 1900-1990). Przegląd Geofizyczny 40, 231-246 [in Polish].

Kożuchowski, K.M., Marciniak, K., 1988. Variability of mean monthly temperatures and semi-annual precipitation totals in Europe in relation to hemispheric circulation patterns. International Journal of Climatology 8, 191-199, https://doi.org/10.1002/joc.3370080206.

Kučerová, M., Beck, C., Philipp, A., Huth, R., 2017. Trends in frequency and persistence of atmospheric circulation types over Europe derived from a multitude of classifications. International Journal of Climatology 37, 2502-2521. DOI: 10.1002/joc.4861.

Lamb, H.H., 1972. Climate: present, past and future, Vol. I, Methuen, London, 1-647.

Lambeck, K., 1980. The Earth's Variable Rotation: Geophysical Causes and Consequences. Cambridge University Press, CambridgeLondon-New York-New Rochelle-Melbourne-Sydney, 1-449.

Marsz, A.A., 1999. Oscylacja Północnoatlantycka a reżim termiczny zim na obszarze północno-zachodniej Polski i na polskim wybrzeżu Bałtyku (North Atlantic Oscillation and thermic regime of winters in NW Poland and the Polish coast of the Baltic sea). Przegląd Geograficzny 71, 225-245 [in Polish].

Marsz, A.A., 2013. Frekwencja makrotypów cyrkulacji środkowotroposferycznej według klasyfikacji Wangengejma-Girsa w okresie zimowym a pole ciśnienia atmosferycznego nad Europą i północną Azją (Frequency of mid-tropospheric circulation macro-types following Wangengejm-Girs classification during winter period and the atmospheric pressure field over Europe and north Asia). Przegląd Geofizyczny 58, 3-23 [in Polish].

Sepp, M., 2005. Influence of atmospheric circulation on environmental variables in Estonia. Dissertationes Geographicae Universitatis Tartuensis 25, 1-84.

Sepp, M., 2011. Režiiminihkest Läänemere regiooni atmosfääri tsirkulatsioonis (Regime shift in atmospheric circulation in the Baltic Sea region). Publicationes Instituti Geographici Universitatis Tartuensis 109, 72-89 [in Estonian].

Sidorenkov, N.S., Orlov, I.A., 2008. Atmospheric circulation epochs and climate changes. Russian Meteorology and Hydrology 33, 553-559, https://doi.org/10.3103/S1068373908090021.

Sidorenkov, N.S., Svirenko, P.I., 1983. K voprosu o mnogoletnikh kolebanyakh atmosfernoy cirkulacyi (Problems of multi-year variations of the atmospheric circulation). Meteorologia i Gidrologia 11, 20-25 [in Russian]. 